\title{
Antistaphylococcal and biofilm inhibitory activities of acetyl-11-keto- $\beta$-boswellic acid from Boswellia serrata
}

\author{
Alsaba F Raja', Furqan Ali², Inshad A Khan², Abdul S Shawll ${ }^{1 *}$, Daljit S Arora ${ }^{3}$, Bhahwal A Shah ${ }^{4}$, Subhash C Taneja ${ }^{4}$
}

\begin{abstract}
Background: Boswellic acids are pentacyclic triterpenes, which are produced in plants belonging to the genus Boswellia. Boswellic acids appear in the resin exudates of the plant and it makes up $25-35 \%$ of the resin. $\beta$ boswellic acid, 11-keto- $\beta$-boswellic acid and acetyl-11-keto- $\beta$-boswellic acid have been implicated in apoptosis of cancer cells, particularly that of brain tumors and cells affected by leukemia or colon cancer. These molecules are also associated with potent antimicrobial activities. The present study describes the antimicrobial activities of boswellic acid molecules against 112 pathogenic bacterial isolates including ATCC strains. Acetyl-11-keto- $\beta$ boswellic acid (AKBA), which exhibited the most potent antibacterial activity, was further evaluated in time kill studies, postantibiotic effect (PAE) and biofilm susceptibility assay. The mechanism of action of AKBA was investigated by propidium iodide uptake, leakage of 260 and $280 \mathrm{~nm}$ absorbing material assays.
\end{abstract}

Results: AKBA was found to be the most active compound showing an MIC range of $2-8 \mu \mathrm{g} / \mathrm{ml}$ against the entire gram positive bacterial pathogens tested. It exhibited concentration dependent killing of Staphylococcus aureus ATCC 29213 up to $8 \times$ MIC and also demonstrated postantibiotic effect (PAE) of $4.8 \mathrm{~h}$ at $2 \times$ MIC. Furthermore, AKBA inhibited the formation of biofilms generated by $S$. aureus and Staphylococcus epidermidis and also reduced the preformed biofilms by these bacteria. Increased uptake of propidium iodide and leakage of 260 and $280 \mathrm{~nm}$ absorbing material by AKBA treated cells of $S$ aureus indicating that the antibacterial mode of action of AKBA probably occurred via disruption of microbial membrane structure.

Conclusions: This study supported the potential use of AKBA in treating S. aureus infections. AKBA can be further exploited to evolve potential lead compounds in the discovery of new anti-Gram-positive and anti-biofilm agents.

\section{Background}

Nosocomial infections pose a significant threat to patients worldwide. Gram-positive bacterial pathogens are a significant cause of nosocomial infections that are important causes of morbidity and mortality [1]. Grampositive bacterial pathogens such as Staphylococcus aureus, Streptococcus pneumonia and Enterococcus faecalis are clinically significant and the antibiotic resistance in these pathogens has become one of the major worldwide health problems. The emergence of methicillin-resistant Staphylococcus aureus (MRSA) and vancomycin-resistant Enterococcus faecium (VRE) are the major clinical

\footnotetext{
* Correspondence: asshawl@gmail.com

${ }^{1}$ Microbiology Unit, Indian Institute of Integrative Medicine (CSIR),

Sanatnagar, Srinagar, 190005, India

Full list of author information is available at the end of the article
}

concerns today [2]. The recent appearance vancomycinintermediate resistant (VISA) and vancomycin-resistant S. aureus isolates (VRSA) in many countries is the latest development in antibiotic resistance [3]. MRSA has now exerted its own impact upon the mortality rate. The average mortality rate from a recent meta-analysis of 30 studies was $\approx 36 \%$ compared against a mortality rate of $\approx 24 \%$ from septicemia caused by methicillin-susceptible S. aureus [4].

Biofilms are communities of surface-associated microorganisms embedded in a self-produced extracellular polymeric matrix that are notoriously difficult to eradicate and are a source of many recalcitrant infections [5-9]. Staphylococci are known to form biofilms on an implanted medical device or damaged tissues and these biofilms are difficult to disrupt [10]. Biofilm infections

\section{Ciomed Central}


are difficult to treat due to their inherent antibiotic resistance [11,12].

Boswellic acids are the major constituents of the gum derived from the plant Boswellia serrata Roxb. ex Colebr. (family Burseraceae, Syn. B. glabra). The gum resin comprises of $\beta$-boswellic acids as the main triterpenic acid along with 11 -keto- $\beta$-boswellic acids and their acetates [13]. The gum exudate is known for its anti-inflammatory properties in the Ayurvedic system of medicines $[14,15]$. The alcoholic extract of the gum is used for the treatment of adjuvant arthritis [16]. It has synergistic effect with glucosamine, an anti-inflammatory and anti-arthritic agent [17]. Acetyl-11-keto- $\beta$ boswellic acid (AKBA), a component of the gum exudate is a pentacyclic terpenoid and is reported to be active against a large number of inflammatory diseases $[18,19]$ including cancer, arthritis, chronic colitis, ulcerative colitis, Crohn's disease, and bronchial asthma [20-22]. In spite of these therapeutic effects of boswellic acids, little is known about their antibacterial activity and the active principle responsible. The aim of this study was to evaluate the antibacterial activity of acetyl11 -keto- $\beta$-boswellic acid and its effect on biofilms generated by $S$. aureus and Staphylococcus epidermidis.

\section{Results}

Minimum inhibitory concentrations (MIC) and minimum bactericidal concentrations (MBC) of boswellic acids

The in vitro antibacterial activities of boswellic acids were tested on a group of clinically significant Grampositive and Gram-negative bacteria (Table 1). AKBA was the most active of the four boswellic acids against the bacterial pathogens. However the activity of AKBA was limited to Gram-positive bacteria only as its MIC was $>128 \mu \mathrm{g} / \mathrm{ml}$ against Escherichia coli ATCC 25292 and Pseudomonas aeruginosa ATCC 27853 (Gram-negative pathogens used in this study). AKBA exhibited MIC ranging from $2-8 \mu \mathrm{g} / \mathrm{ml}$ against all the Gram-positive clinical isolates tested, whereas 11 -keto- $\beta$-boswellic acid
(KBA) and $\beta$-boswellic acid (BA) exhibited moderate Gram-positive antibacterial activity $(\mathrm{MIC} \approx 8-64 \mu \mathrm{g} / \mathrm{ml}$ ). Acetyl- $\beta$-boswellic acid (ABA) on the other hand was completely devoid of antibacterial activity upto the tested concentration of $128 \mu \mathrm{g} / \mathrm{ml}$. All the compounds were bacteriostatic in nature and exhibited an $\mathrm{MBC}$ $>128 \mu \mathrm{g} / \mathrm{ml}$. Since AKBA was found to be the most active boswellic acid compound against Gram-positive bacterial pathogens, further in vitro studies were performed on this compound against clinically important S. aureus and S. epidermidis.

\section{Postantibiotic Effect (PAEs)}

The PAE of AKBA was determined on S. aureus ATCC 29213 (Table 2). The PAE induced by AKBA was concentration dependent, with duration $3.0 \pm 0.1 \mathrm{~h}$ at $1 \times$ MIC while at $2 \times \mathrm{MIC}$ it was $4.8 \pm 0.1 \mathrm{~h}$. Ciprofloxacin was used as control drug in the study and it exhibited a $\mathrm{PAE}$ of $1.4 \pm 0.05 \mathrm{~h}$ at $1 \times \mathrm{MIC}$ while at $2 \times \mathrm{MIC}$ it was $2.2 \pm 0.1 \mathrm{~h}(0.5 \mu \mathrm{g} / \mathrm{ml})$. The PAEs of AKBA were significantly higher than the ciprofloxacin against $S$. aureus $(P<0.05)$.

\section{Time-kill kinetic studies}

The time-kill kinetic studies of AKBA were performed on S. aureus ATCC 29213 (Figure 1). It showed bacteriostatic activity at all the tested concentrations. The maximum effect of AKBA was observed at 16 and $32 \mu \mathrm{g} / \mathrm{ml}$ exhibiting $\mathrm{a} \approx 2 \log _{10}$ reduction in the viability of $S$. aureus cells when compared with non treated controls $(P<0.05)$ at four and eight times it's MIC over a period of 24 h study.

\section{Biofilm inhibition and reduction}

AKBA effectively inhibited the formation of S. aureus and S. epidermidis biofilms, with $50 \%$ biofilm inhibition concentration $\left(\mathrm{MBIC}_{50}\right.$ ) from 16-32 $\mu \mathrm{g} / \mathrm{ml}$ (as derived from Figure $2 \mathrm{~A}$ ) which is in the range of $4 \times \mathrm{MIC}$ and $8 \times$ MIC respectively. AKBA also effectively eradicated

Table 1 Antibacterial activity of boswellic acid molecules against bacterial pathogens

\begin{tabular}{|c|c|c|c|c|c|c|}
\hline \multirow[t]{2}{*}{ Organisms $\left(\mathrm{Cl}^{\mathrm{n}}\right)$} & \multirow[b]{2}{*}{ Ciprofloxacin } & \multirow{2}{*}{$\frac{\mathrm{KBA}}{\mathrm{MIC}^{\mathrm{a}}}$} & \multirow{2}{*}{$\frac{\mathrm{AKBA}}{\mathrm{MIC}^{\mathrm{a}}}$} & \multirow{2}{*}{$\frac{\mathrm{BA}}{\mathrm{MIC}^{\mathrm{a}}}$} & \multicolumn{2}{|l|}{$\mathrm{ABA}$} \\
\hline & & & & & $\mathrm{MIC}^{\mathrm{a}}$ & $\mathrm{MBC}^{\mathrm{b}}$ \\
\hline S. aureus ATCC-29213 & 0.25 & 16 & 2 & 32 & $>128$ & $>128$ \\
\hline MRSA ATCC 3591, (50) & $8->16$ & $16-32$ & $2-4$ & $32-64$ & $>128$ & $>128$ \\
\hline E. faecalis ATCC 29212, (22) & $0.25-16$ & $16-32$ & $4-8$ & $8-16$ & $>128$ & $>128$ \\
\hline E. faecium ATCC 8042, (18) & $0.25-16$ & $16-32$ & $4-8$ & $8-16$ & $>128$ & $>128$ \\
\hline S. epidermidis ATCC 12228,(12) & $0.25->16$ & $8-16$ & $4-8$ & $32-64$ & $>128$ & $>128$ \\
\hline Vancomycin resistant E. faecalis (10) & $>16$ & $8-16$ & $2-8$ & $8-16$ & $>128$ & $>128$ \\
\hline E. coli ATCC 25292 & 0.03 & $>128$ & $>128$ & $>128$ & $>128$ & $>128$ \\
\hline P. aeruginosa ATCC 27853 & 0.12 & $>128$ & $>128$ & $>128$ & $>128$ & $>128$ \\
\hline
\end{tabular}

MICs and MBCs of boswellic acid molecules were determined using CLSI guidelines against 115 clinical isolates including ATCC strains. ${ }^{a}$ Minimum Inhibitory Concentration $(\mu \mathrm{g} / \mathrm{ml})$; ${ }^{b}$ Minimum Bactericidal Concentration $(\mu \mathrm{g} / \mathrm{ml}) ; \mathrm{Cl}=$ Clinical isolates; $\mathrm{n}=$ number of clinical isolates. 
Table 2 PAEs of Acetyl-11-keto- $\beta$-boswellic acid against S. aureus ATCC 29213

\begin{tabular}{lll}
\hline Compounds & \multicolumn{2}{l}{ Mean PAE (h) \pm SD on: } \\
\cline { 2 - 3 } & $\mathbf{1} \times \mathbf{M I C}$ & $\mathbf{2} \times \mathbf{M I C}$ \\
\hline Acetyl-11-keto- $\beta$-boswellic acid & $3.0 \pm 0.1^{\mathrm{a}}$ & $4.8 \pm 0.1^{\mathrm{b}}$ \\
Ciprofloxacin & $1.4 \pm 0.05^{\mathrm{a}}$ & $2.2 \pm 0.1^{\mathrm{b}}$ \\
\hline
\end{tabular}

The PAEs were monitored by viable count of $S$. aureus after $2 \mathrm{~h}$ exposure to concentrations equal to MIC and $2 \times$ MIC of antimicrobials (AKBA and ciprofloxacin). Values in the same column followed by the same superscripts are significantly different from each other $(P<0.05$; Student's $t$ test). PAE, Post antibiotic effect.

the preformed biofilms. The $50 \%$ biofilm reduction concentration $\left(\mathrm{MBRC}_{50}\right)$ ranged from $32-64 \mu \mathrm{g} / \mathrm{ml}$ for both the bacterial isolates (Figure $2 \mathrm{~B}$ ).

\section{Effect of AKBA on membrane integrity}

In order to investigate the antibacterial action of AKBA on the bacterial membrane integrity, the cell suspension of $S$. aureus ATCC 29213 was exposed to a concentration of $64 \mu \mathrm{g} / \mathrm{ml}$ AKBA for 60 and 120 min followed by staining with propidium iodide (nucleic acid stain). The AKBA exposure resulted in bacterial cell membrane disruption as evident from the increased uptake of propidium iodide in comparison to the unexposed cells $(P<$ 0.05) (Figure 3). In addition, the membrane leakage assay illustrated the cytoplasmic membrane damage of S. aureus. The amount of 260 and $280 \mathrm{~nm}$ absorbing material in $S$. aureus cell supernatants treated with
AKBA (relative to the total released upon complete cell lysis) was 12 and $15 \%$ at $90 \mathrm{~min}$ while it was 15 and $19 \%$ at 120 min respectively (Figure 4 ), which was significantly higher than the untreated control $(P<0.05)$.

\section{Discussion and conclusion}

The gum exudate or the resin obtained from the bark of Boswellia serrata has been widely used by the practitioners of the Indian systems of medicine for various medical conditions such as arthritis, asthma, ulcers, and skin diseases; currently it is being extensively used in various formulations for the treatment of inflammation related disorders [13-15]. The major chemical components of gum resin can be divided into three groups: volatile oils or lower terpenoids, higher terpenoids, and carbohydrates. The higher terpenoids comprises of $\beta$-boswellic acids as the main triterpenic acid along with 11-keto- $\beta$-boswellic acids and their acetates [23].

The in vitro antibacterial activity results of four boswellic acid compounds revealed AKBA to be the most potent antibacterial compound against Gram-positive pathogens, but it showed no significant antibacterial activity (MIC $>128 \mu \mathrm{g} / \mathrm{ml}$ ) against the Gram negative bacteria. AKBA exerted bacteriostatic antibacterial activity against S. aureus ATCC 29213 (Figure 1) and exhibited a good PAE of $4.8 \mathrm{~h}$ at $2 \times$ MIC concentration. Staphylococci cause a large percentage of catheter associated infections, and like many other pathogens, rather

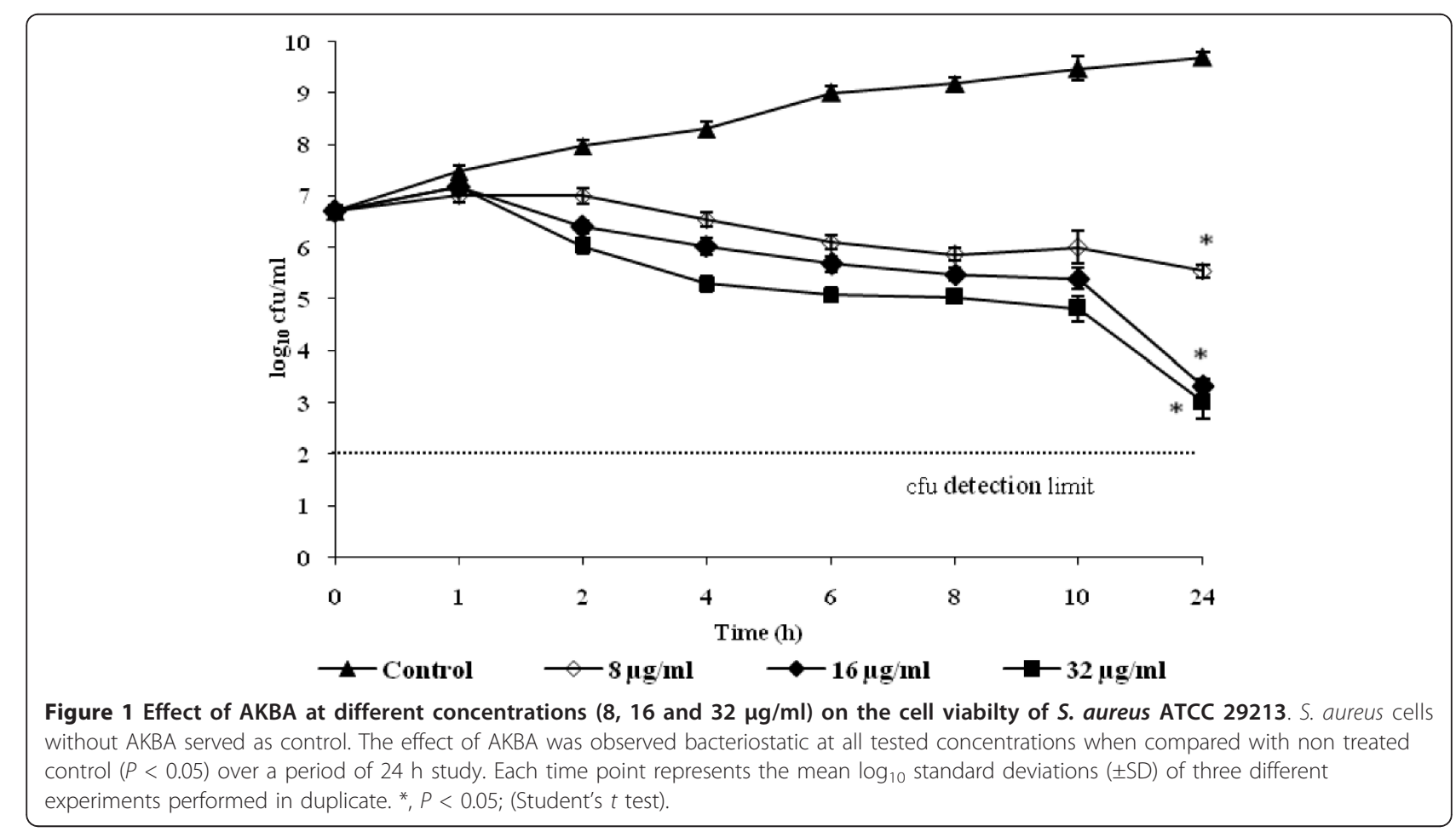



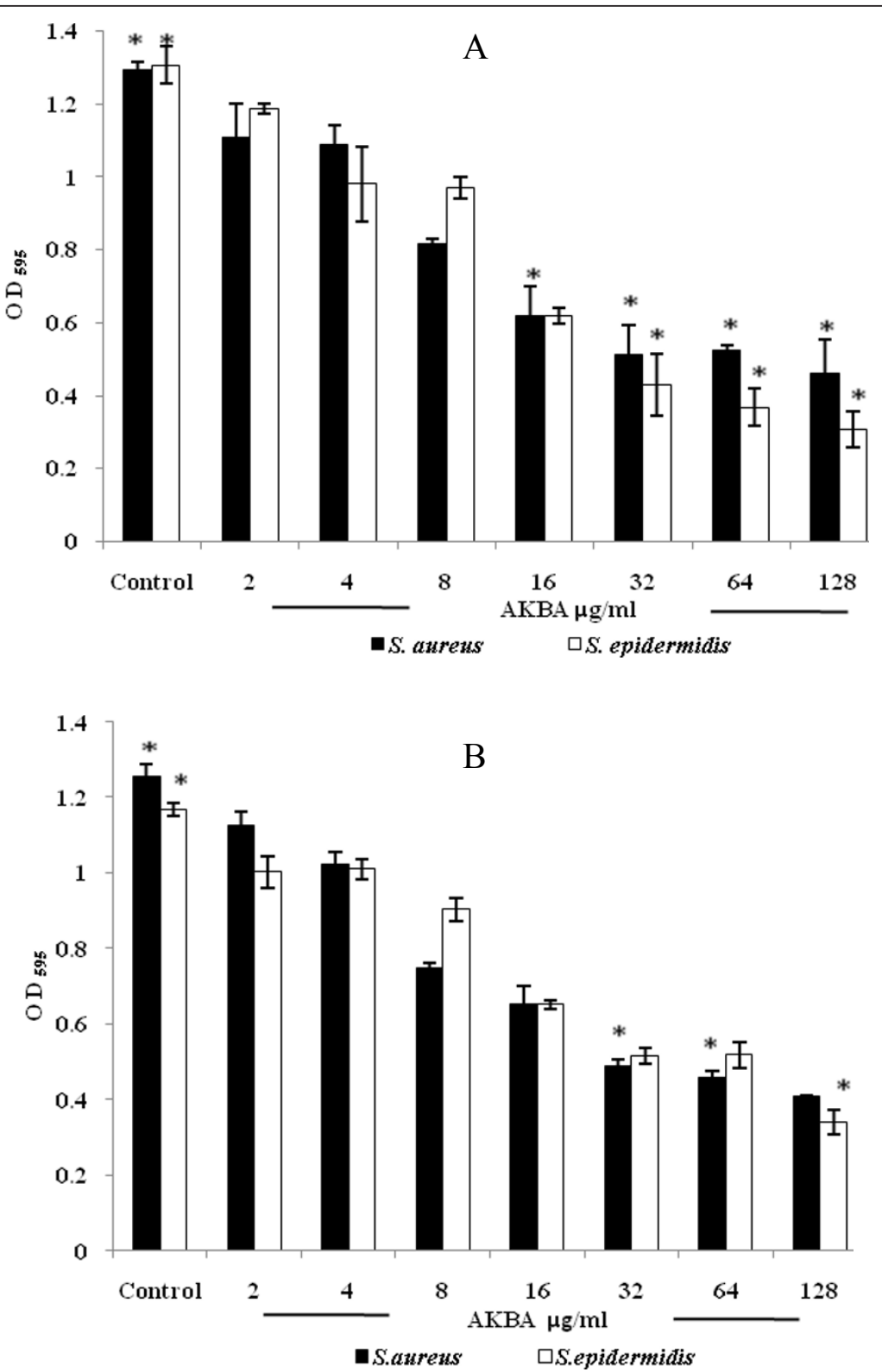

Figure 2 Effect of AKBA on the biofilm formation (A) and preformed biofilm (B) by S. aureus ATCC 29213 and S. epidermidis ATCC 12228. After incubation, the biofilms were stained with crystal violet and the optical density of stained adherent bacteria was determined with a multidetection microplate reader at a wavelength of $595 \mathrm{~nm}\left(\mathrm{OD}_{595}\right)$. The results are expressed as average optical density readings for crystal violet assays compared to growth control. The biofilm of S. aureus and S. epidermidis were significantly inhibited (A) and reduced (B) compared with those of bacteria without AKBA $(P<0.01)$. Values are mean $( \pm \mathrm{SD})$ from four independent determinations. ${ }^{*}, P<0.01$ (Student's $t$ test).

than living as free planktonic cells within the host they tend to form a multilayered community of sessile bacterial cells known as a biofilm on medical implants or damaged tissue $[7,24,12]$. Biofilm infections are difficult to treat due to their inherent antibiotic resistance $[7,12,25]$. AKBA effectively inhibited the staphylococcal biofilm and also reduced the preformed biofilm of these bacterial pathogens $(P<0.01)$. To our knowledge, this is the first report to provide the evidence that AKBA can prevent as well as reduce the S. aureus and S. epidermidis generated biofilms.

AKBA is reported to be active against a large number of inflammatory diseases, cancer, arthritis, chronic colitis, ulcerative colitis, Crohn's disease, and bronchial asthma $[21,26,20,27,28]$. The anticancer activity of AKBA is attributed to the inhibitory effect on the lipoxygenases leading to the inhibition of cell proliferation and induction of apoptosis in tumor cells [29]. There 


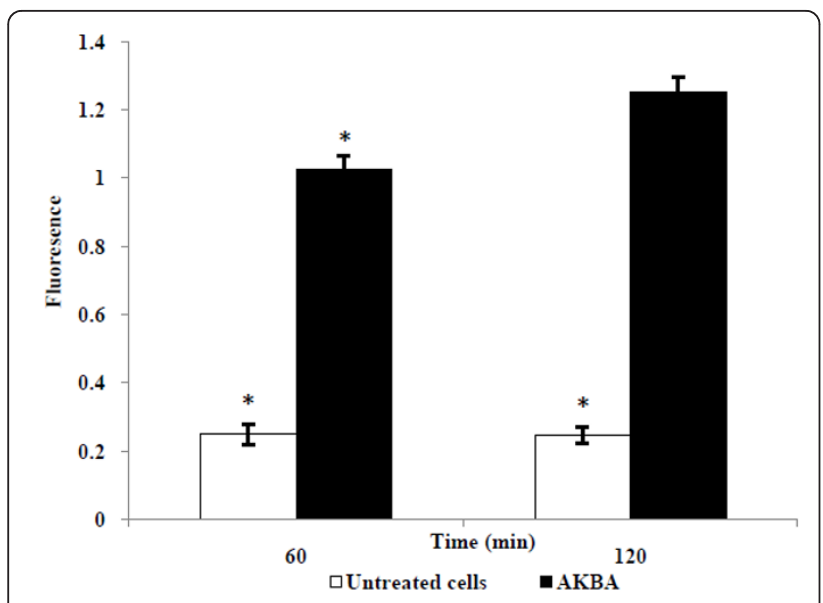

Figure 3 Uptake of propidium iodide in cell of S. aureus ATCC 29213. Cells of S. aureus were treated with AKBA at $64 \mu \mathrm{g} / \mathrm{ml}$ for 60 and 120 min. Control group included cells untreated with AKBA. AKBA treated cells significantly increases the fluorescence compared with untreated control $(P<0.05)$. Data represent the mean and standard deviations $( \pm S D)$ of two different experiments performed in triplicate. ${ }^{*}, P<0.05$ (Student's $t$ test).

are numerous reports available on the antibacterial activity of oleo-gum resin extracts and oleo-gum resin essential oils from Boswellia spp. (Burseraceae) [30-32]. Weckessera et al. [33] reported the antibacterial activity of Boswellia dry extract and keto-ß-boswellic acid. Their findings revealed that the extract was highly effective against selected aerobic and anaerobic bacteria such as Streptococcus, Corynebacteria, C. perfringens and $P$. acnes; whereas KBA was not effective against these pathogens, suggesting that the effective components are other boswellic acids or essential oils contained in the extract. In this study, we extensively evaluated the boswellic acids for the antibacterial activity and further for the first time established that AKBA is the single most potent antibacterial compound present in the gum exudates of Boswellia serrata.

We further investigated the effect of AKBA on the bacterial cell membrane integrity through propidium iodide uptake assay. Propidium iodide is fluorescent nucleic acid stain that binds to DNA by intercalating between the bases with little or no sequence preference. It is membrane impermeant and generally excluded from viable cells. The increased uptake of propidium iodide in the AKBA treated cells of $S$ aureus in our study indicated that AKBA altered the cell membrane structure, resulting in the disruption of the permeability barrier of microbial membrane structures. Leakage of cytosolic constituents (260 and $280 \mathrm{~nm}$ absorbing materials) from S. aureus cells in the presence $64 \mu \mathrm{g} / \mathrm{ml}$ AKBA over a period of two h was significantly higher than background levels $(P<0.05)$. These observations indicate that the antimicrobial activity of AKBA results from its ability to disrupt the permeability barrier of microbial membrane structures. The lack of antibacterial activity of AKBA against Gram-negative bacteria may be attributed due to the presence of lipophilic outer membrane. This outer layer of the Gram-negative outer membrane is composed primarily of lipopolysaccharide molecules and forms a hydrophilic permeability barrier providing protection against the effects of highly hydrophobic compounds [34,35]. This may be the probable explanation of the resistance of Gram-negative bacteria to lipophilic AKBA. Similar

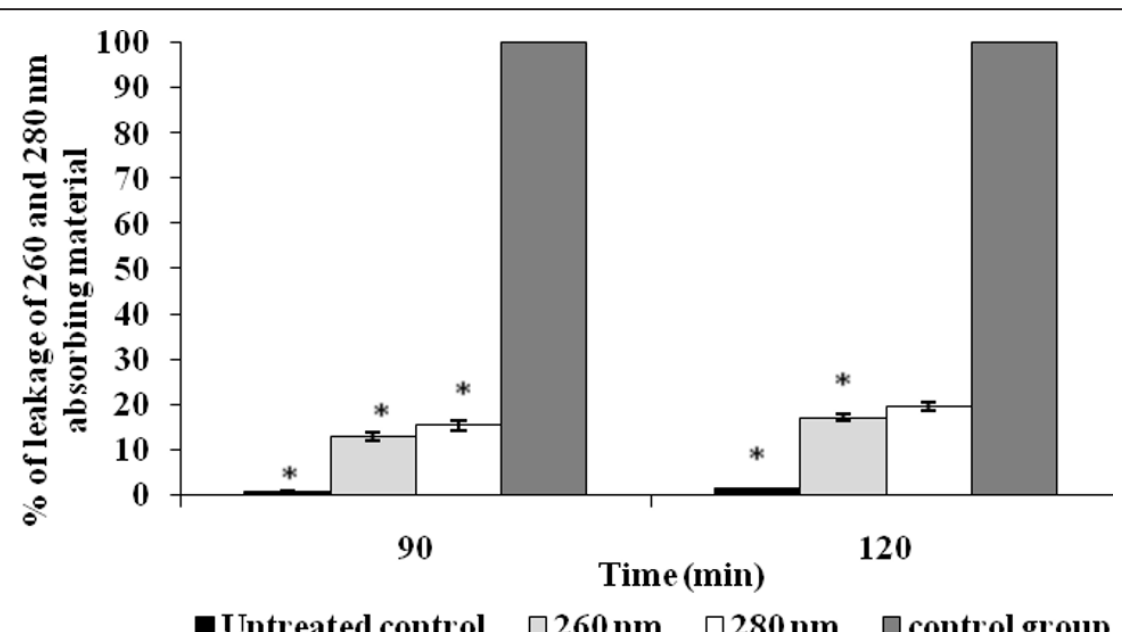

Figure 4 Effect of AKBA on the leakage of 260 and $280 \mathrm{~nm}$ absorbing materials in S. aureus ATCC cells. Control group (treated with lytic enzymes and considered as 100\% leakage) and treated with AKBA at $64 \mu \mathrm{g} / \mathrm{ml}$ for 90 and $120 \mathrm{~min}$. No compound added served as untreated control. Values are means $\left( \pm\right.$ SD) from three independent determinations. ${ }^{*}, P<0.05$ (Student's $t$ test), AKBA treated group compared to untreated control group. 
observations have been made in other studies also, where lipohilic terpenes such as carvacrol, thymol, eugenol, geraniol, linalyl acetate, (-) menthol and bakuchiol have reported low sensitivities against Gram-negative bacteria [36-38].

Gum resin of boswellia is included in the list of substances Generally Recognized As Safe (GRAS), thereby permitting its use as food additive by US FDA. Boswellic acid extract and AKBA have also been reported to be safe and exert minimal toxicity on human skin cells [39]. The recent study indicates that $B$. serrata is nonmutagenic in Ames test, and is non-clastogenic in in vitro chromosomal aberration study [40]. Oral preparations of Boswellic serrata extract containing AKBA are sold in the market as over the counter (OTC) antiinflammatory formulations and are considered to be quite safe [41]. The ancient Indian system of medicine (Ayurveda) claims these preparations to be safe and effective dietary supplement against joint disorders $[42,14,15]$. Preliminary pharmacokinetic studies carried out in humans yielded low concentrations of boswellic acids in plasma [43-45]. In the study reported by Buechele and Simmet [44] AKBA was found in plasma at a concentration of $0.1 \mu \mathrm{M}$ after the daily intake of $4 \times$ $786 \mathrm{mg}$ Boswellia extract for 10 days. In accordance with the observations made in humans, KBA and AKBA were detected at a concentration of 0.4 and $0.2 \mu \mathrm{M}$, respectively; in rat plasma following single oral dose administration of $240 \mathrm{mg} / \mathrm{kg}$ Boswellia serrata extract [46]. Further attempts should be made to improve the bioavailability of AKBA through lipid based delivery systems. As the literature suggested that the intake of a high fat meal increases three to fivefold in the plasma concentrations of boswellic acid molecules [47].

In addition to the above reported usage and safety associated with AKBA, the potent antibacterial activity reported in this study warrants that the structure of AKBA can be further exploited to evolve potential lead compounds in the discovery of new anti-Gram-positive and anti-biofilm agents.

\section{Methods}

Extraction and isolation of boswellic acid molecules from gum resin of Boswellia serrata

BA, KBA, ABA and AKBA were obtained from Bioorganic Chemistry Division of Indian Institute of Integrative Medicine Jammu, India. The extraction, isolation, and quantification of these compounds from gum resin of Boswellia serrata were described in our previous study $[17,23]$.

\section{Bacterial strains and culture conditions}

The bacterial strains used in this study were $S$. aureus ATCC 29213, methicillin-resistant S. aureus (MRSA)
ATCC 33591, E. faecalis ATCC 29212, E. faecium ATCC 8042, S. epidermidis ATCC 12228, E. coli ATCC 25292, P. aeruginosa ATCC 27853 and 112 isolates of various bacterial pathogens (MRSA 50, E. faecalis 22, E. faecium 18, S. epidermidis 12 and vancomycin resistant $E$. faecalis 10). All ATCC strains were procured from the American Type Culture Collection (ATCC, Manassas, VA, USA). Clinical isolates of all strains were kindly gifted by Ranbaxy Laboratories Limited, India and Lupin pharmaceutical, Pune, India. The cultures were stored at $-70^{\circ} \mathrm{C}$ in trytone soya broth containing 50\% glycerol (vol/vol; Himedia, Mumbai India) and maintained on tryptic soy agar (TSA; Difco Laboratories, Detroit, Mich USA).

Determination of minimum inhibitory concentration (MIC) and minimum bactericidal concentrations (MBC)

MIC was determined as per the guidelines of Clinical and Laboratory Standards Institute (formerly the National Committee for Clinical Laboratory Standards) [48]. Briefly, the bacterial suspensions were prepared by suspending $18 \mathrm{~h}$ grown bacterial culture in sterile normal saline $(0.89 \% \mathrm{NaCl}$ wt/vol; Himedia, Mumbai India). The turbidity of the bacterial suspension was adjusted to 0.5 McFarland standards (equivalent to $1.5 \times 10^{8} \mathrm{col}-$ ony forming units $(\mathrm{CFU}) / \mathrm{ml})$. The boswellic acids stock solutions were prepared in $100 \%$ dimethyl sulfoxide (DMSO; Merck, Mumbai India) and 2-fold serial dilutions were prepared in Mueller Hinton Broth (MHB; Difco Laboratories) in $100 \mu \mathrm{l}$ volume in 96-well $\mathrm{U}$ bottom microtiter plates (Tarson, Mumbai, India). The above-mentioned bacterial suspension was further diluted in the MHB and $100 \mu$ l volume of this diluted inoculum was added to each well of the plate resulting in the final inoculum of $5 \times 10^{5} \mathrm{CFU} / \mathrm{ml}$ in the well and the final concentration of boswellic acids ranged from 0.25 to $128 \mu \mathrm{g} / \mathrm{ml}$. Ciprofloxacin was used as standard antibacterial agent for this study at a concentration ranged from $0.03-16 \mu \mathrm{g} / \mathrm{ml}$. The plates were incubated at $37^{\circ} \mathrm{C}$ for $18 \mathrm{~h}$ and were visually read for the absence or presence of turbidity. The minimum concentration of the compound concentration showing no turbidity was recorded as MIC. The MBC was determined by spreading $100 \mu \mathrm{l}$ volume on tryptic soy agar (TSA) plate from the wells showing no visible growth. The plates were incubated at $37^{\circ} \mathrm{C}$ for overnight.

\section{Time kill assay}

S. aureus ATCC 29213 was grown in $\mathrm{MHB}$ at $37^{\circ} \mathrm{C}$ for $24 \mathrm{~h}$. The turbidity of the suspension was adjusted to 0.5 McFarland standard $\left(\approx 1.5 \times 10^{8} \mathrm{CFU} / \mathrm{ml}\right)$ in sterile normal saline. Two hundred microliters of this suspension was used to inoculate $20 \mathrm{ml}$ of $\mathrm{MHB}$ in conical flasks containing AKBA in the concentration range of 
8-32 $\mu \mathrm{g} / \mathrm{ml}$. DMSO controls were also included in the study. The flasks were incubated at $37^{\circ} \mathrm{C}$. One hundred microliters samples were taken at $0,1,2,4,6,8,10$, and $24 \mathrm{~h}$ and the viable counts were determined in triplicate on TSA. Killing curves were constructed by plotting the $\log _{10} \mathrm{CFU} / \mathrm{ml}$ versus time over $24 \mathrm{~h}$ [49].

\section{Postantibiotic Effect (PAE)}

The PAEs of the AKBA were assessed by the method described by Craig and Gudmundsson [50]. AKBA was added at the MIC and $2 \times$ MIC to test tubes containing $\approx 10^{6} \mathrm{CFU} / \mathrm{ml}$ of S. aureus ATCC 29213 in MHB broth. After an exposure of $2 \mathrm{~h}$ to the AKBA, samples were diluted to 1:1,000 in same medium to effectively remove AKBA. CFU was determined from the sample every hour until visual cloudiness was noted. The PAE was calculated by the equation: $\mathrm{PAE}=T-C$, where $T$ represents the time required for the count in the test culture to increase $1 \log _{10} \mathrm{CFU} / \mathrm{ml}$ above the count observed immediately after drug removal and $C$ represents the time required for the count of the untreated control tube to increase by $1 \log _{10} \mathrm{CFU} / \mathrm{ml}$.

\section{Biofilm susceptibility assay}

The biofilms of S. aureus ATCC 29213 and S. epidermidis ATCC 12228 were prepared in 96-well flat-bottom polystyrene microtiter plates (Tarson, Mumbai, India), using a previously described method of Wei et al. [51] with a few modifications. This method was similar to the MIC assay for planktonic cells. The bacterial suspensions were prepared from the overnight grown culture and the turbidity of the suspension was adjusted to 0.7 O.D.610 $\left(\approx 1 \times 10^{9} \mathrm{CFU} / \mathrm{ml}\right)$. Twofold serial dilutions of boswellic acids were prepared in $100 \mu \mathrm{l}$ volume in tryptone soya broth (TSB; Difco laboratories) supplemented with $0.5 \%$ glucose in the wells of 96 -well flat bottom microtiter plate. Forty microliters of fresh TSB with $0.5 \%$ glucose was added to each well, followed by the addition of $60 \mu \mathrm{l}$ of above bacterial suspension. This resulted in the final inoculum of $6 \times 10^{7} \mathrm{CFU} / \mathrm{ml}$ in each well: the final concentrations of the compounds ranged from (0.12 to $128 \mu \mathrm{g} / \mathrm{ml})$. The plate was incubated for $18 \mathrm{~h}$ at $37^{\circ} \mathrm{C}$. After completion of incubation, the planktonic cells were removed from each well by washing with phosphate buffer saline (Himedia, Mumbai, India). The biofilms were fixed with methanol for 15-30 min, stained with 0.1\% (wt/vol) Crystal Violet (Sigma Chemical Co., St Louis, MO, USA) for 10 min and rinsed thoroughly with water until the negative control wells appeared colorless. Biofilm formation was quantified by the addition of $200 \mu \mathrm{l}$ of $95 \%$ ethanol to the crystal violet stained wells and recording the absorbance at $595 \mathrm{~nm}\left(\mathrm{~A}_{595}\right)$ using a microplate reader (Multiskan spectrum, Thermo electron, Vantaa, Finland).
The effect of AKBA was also examined on preformed biofilms. The biofilms were prepared by inoculating the suspension of $S$. aureus and $S$. epidermidis into the wells of a polystyrene microtiter plate as mentioned above. After incubation at $37^{\circ} \mathrm{C}$ for $18 \mathrm{~h}$, the culture supernatant from each well was decanted and planktonic cells were removed by washing the wells with PBS ( $\mathrm{pH}$ 7.2). Two fold serial dilution of AKBA was prepared in TSB and 200 $\mu \mathrm{l}$ of each dilution was added to the biofilm in the wells. The plate was further incubated at $37^{\circ} \mathrm{C}$ for $18 \mathrm{~h}$. The biofilm was fixed, stained and quantified as described above.

\section{Propidium iodide uptake assay}

The action of AKBA on cell membrane permeability of $S$. aureus ATCC 29213 cells was evaluated by the method as described by Cox et al. [52]. The bacterial cells were grown overnight in $100 \mathrm{ml}$ of $\mathrm{MHB}$ at $37^{\circ} \mathrm{C}$, washed and resuspended in 50-mmol/l sodium phosphate buffer, $\mathrm{pH}$ $7 \cdot 1$. The turbidity of the suspension was adjusted to 0.7 O.D. $610\left(\approx 1 \times 10^{9} \mathrm{CFU} / \mathrm{ml}\right)$. One milliliter volume of this suspension was added to flask containing $19 \mathrm{ml}$ buffer and $64 \mu \mathrm{g} / \mathrm{ml}$ of AKBA. Following 60 and $120 \mathrm{~min}$ incubation at room temperature, $50 \mu \mathrm{l}$ aliquots were transferred into Eppendorfs tubes containing $950 \mu \mathrm{l}$ phosphate buffer in FACS tubes (Becton Dickinson Biosciences, CA, USA). These tubes were stored on ice and 5 $\mu \mathrm{l}$ of staining solution, consisting of $2.5 \mathrm{mg} / \mathrm{ml}$ propidium iodide (Sigma) dissolved in milliQ water, was added in the final propidium iodide concentration of $10 \mu \mathrm{g} / \mathrm{ml}$. The cells were subjected to FACS analysis [53,54], on the flow cytometer (BD-LSR, Becton Dickinson).

\section{Leakage of 260 and $280 \mathrm{~nm}$ absorbing compounds}

The release of 260 and $280 \mathrm{~nm}$ absorbing compounds was determined spectrophotometrically [55]. Briefly, cells suspensions of $S$. aureus were prepared as for propidium iodide uptake assay. AKBA was added at $64 \mu \mathrm{g} / \mathrm{ml}$ to the bacterial suspension $\left(\approx 1 \times 10^{9} \mathrm{CFU} / \mathrm{ml}\right)$ and incubated for $120 \mathrm{~min}$ at $37^{\circ} \mathrm{C}$. For the complete release of 260 and $280 \mathrm{~nm}$ absorbing compounds, the bacterial suspension (control) was treated with lysozyme $(100 \mu \mathrm{g} / \mathrm{ml})$ at $37^{\circ} \mathrm{C}$ for $120 \mathrm{~min}$, followed by sonication. Cell supernatants were obtained by centrifugation $(10,000 \mathrm{~g}$ for $10 \mathrm{~min})$. The absorbance of cell supernatant at 260 and $280 \mathrm{~nm}$ was determined using spectrophotometer (Multiskan Spectrum). Background leakage rates (no compounds added) were used as untreated control. The extent of leakage of 260 and $280 \mathrm{~nm}$ absorbing compounds was expressed as percentage of control (suspension treated with lysozyme) measured in supernatants.

\section{Statistical analysis}

All experiments were carried out in triplicates in at least three different occasions. Differences between two 
means were evaluated by the Student's $t$-test. The data were analyzed by one-way ANOVA for comparison of multiple means followed by post bonferroni test using GraphPad Instat2 program (GraphPad software Inc. San Diego CA). The chosen level of significance for all statistical tests was $P<0.05$.

\section{Acknowledgements}

The authors thankfully acknowledge the Ranbaxy Laboratories Limited, India for providing clinical Isolates. We would like to thank Scientific Faculty members of IIIM Srinagar, for critical reading of the manuscript. This work was funded by the Council of Scientific and Industrial Research, New Delhi, India (research grant no. P-81-101/2010 SRF (A.F.R.)

\section{Author details}

${ }^{1}$ Microbiology Unit, Indian Institute of Integrative Medicine (CSIR), Sanatnagar, Srinagar, 190005 , India. ${ }^{2}$ Clinical Microbiology Division, Indian Institute of Integrative Medicine (CSIR), Canal Road, Jammu, 180001, India. ${ }^{3}$ Department of Microbiology, Guru Nanak Dev University, Amritsar Punjab143005, India. ${ }^{4}$ Bioorganic Chemistry, Indian Institute of Integrative Medicine (CSIR), Canal Road, Jammu, 180001, India.

\section{Authors' contributions}

AFR, FA and IAK have made substantial contributions to conception and design, acquisition of data, analysis and interpretation of data. ASS and DSA have been involved in drafting the manuscript and revising it critically for important intellectual content. BAS and SCT provided the all four Boswellic acid molecules. All Authors helped to draft the manuscript, participated sufficiently in the work to take public responsibility for appropriate portions of the content and approved the final manuscript.

Received: 24 September 2010 Accepted: 16 March 2011

Published: 16 March 2011

\section{References}

1. Tacconelli E, Angelis GD, Cataldo AM, Pozzi E, Cauda R: Does antibiotic exposure increase the risk of methicillin-resistant Staphylococcus aureus (MRSA) isolation? A systematic review and meta-analysis. J Antimicrob Chemother 2008, 61:26-38.

2. Millar BC, Prendergast BD, Moore JE: Community-associated MRSA (CAMRSA): an emerging pathogen in infective endocarditis. $J$ Antimicrob Chemother 2008, 61:1-7.

3. Hiramatsu K: Vancomycin-resistant Staphylococcus aureus: a new model of antibiotic resistance. Lancet Infect Dis 2001, 1:1470-55.

4. Dancer SJ: The effect of antibiotics on methicillin-resistant Staphylococcus aureus. J Antimicrob Chemother 2008, 61:246-253.

5. Brown MR, Allison DG, Gilbert P: Resistance of bacterial biofilms to antibiotics: a growth-rate related effect? J Antimicrob Chemother 1998, 22:777-780.

6. Chambers HF: The changing epidemiology of Staphylococcus aureus. Emerg. Infect Dis 2001, 17:178-182.

7. Stewart PS: Mechanisms of antibiotic resistance in bacterial biofilms. Int $J$ Med Microbio 2002, 292:107-113.

8. Shirtliff ME, Mader JT, Camper AK: Molecular interactions in biofilms. Chem Biol 2002, 9:859-865.

9. Adam B, Baillie GS, Douglas LJ: Mixed species biofilms of Candida albicans and Staphylococcus epidermidis. J Med Microbiol 2002, 51:344-349.

10. Wu JA, Kusuma C, Mond JJ, Kokai-Kun JF: Lysostaphin Disrupts Staphylococcus aureus and Staphylococcus epidermidis Biofilms on Artificial Surfaces. Antimicrob Agents Chemother 2003, 47:3407-3414.

11. Costerton J: Introduction to biofilm. Inter J Antimicro Agents 1999, 11:217-221.

12. Donlan RM, Costerton JW: Biofilms: survival mechanisms of clinically relevant microorganisms. Clin Microbiol Rev 2002, 15:167-193.

13. Yuan $G, H e$ G, Yang ML: Natural products and anti-inflammatory activity. Asia Pacific J Clin Nutrition 2006, 15:143-152.

14. Kirtikar KR, Basu BD: In Indian Medicinal Plants. M/s Periodical Experts. Delhi, India; 2 1935:1:521.
15. Chatterjee GK, Pal SD: Anti-inflammatory agents from Indian medicinial Plants. Indian Drugs 1984, 21:431.

16. Moore PD: Conservation biology: Unkind cuts for incense. Nature 2006, 444:829.

17. Singh S, Khajuria A, Taneja SC, Khajuria RK, Singh J, Qazi GN: Boswellic acids and glucosamine show synergistic effect in preclinical antiinflammatory study in rats. Bioorg Med Chem Lett 2007, 17:3706-3711.

18. Safayhi H, Sailer ER, Ammon HP: Mechanism of 5-lipoxygenase inhibition by acetyl-11-keto-beta-boswellic acid. Mol Pharmacol 1995, 47:1212-1216.

19. Safayhi H, Rall B, Sailer ER, Ammon HP: Inhibition by boswellic acids of human leukocyte elastase. J Pharmacol Exp Ther 1997, 281:460-463.

20. Krieglstein CF, Anthoni C, Rijcken EJ, Laukotter M, Spiegel HU, Boden SE, Schweizer S, Safayhi H, Senninger N, Schurmann G: Acetyl-11-keto-betaboswellic acid, a constituent of a herbal medicine from Boswellia serrata resin, attenuates experimental ileitis. Int J Colorectal Dis 2001, 16:88-95.

21. Gerhardt H, Seifert F, Buvari P, Vogelsang H, Repges R: Therapy of active Crohn disease with Boswellia serrata extract H 15. Z Gastroenterol 2001, 39:11-17.

22. Kimmatkar $N$, Thawani $V$, Hingorani L, Khiyani R: Efficacy and tolerability of Boswellia serrata extract in treatment of osteoarthritis of knee-a randomized double blind placebo controlled trial. Phytomed 2003, 10:3-7.

23. Pardhy RS, Bhattacharya SC: Boswellic acid, acetyl- b-boswellic, acid-11keto-b-boswellic acid and 11-keto- $\beta$-boswellic acids from the resin of Boswellia serrata Roxb. Ind J Chem 1978, 16B:176-178.

24. Costerton J, Stewart P, Greenberg E: Bacterial biofilms: a common cause of persistent infections. Science 1999, 284:1318-1322.

25. Dunne WM Jr: Bacterial adhesion: seen any good biofilms lately? Clin Microbiol Rev 2002, 15:155-166.

26. Gupta I, Parihar A, Singh GB, Ludtke R, Safayhi H, Ammon HP: Effects of Boswellia serrata gum resin in patients with ulcerative colitis. Eur $J$ Med Res 1997, 2:37-43.

27. Reddy GK, Dhar SC: Effect of a new non-steroidal anti-inflammatory agent on lysosomal stability in adjuvant induced arthritis. Ital I Biochem 1987, 36:205-217.

28. Sharma ML, Bani S, Singh GB: Anti-arthritic activity of boswellic acids in bovine serum albumin (BSA)-induced arthritis. Int I Immunopharma 1989, 11:647-652.

29. Anderson KM, Seed T, Plate JM, Jajeh A, Meng J, Harris JE: Selective inhibitors of 5-lipoxygenase reduce CML blast cell proliferation and induce limited differentiation and apoptosis. Leukotr Res 1993, 19:789-801.

30. Abdallah EM, Khalid AS, Ibrahim N: Antibacterial activity of oleo-gum resins of Commiphora molmol and Boswellia papyrifera against methicillin resistant Staphylococcus aureus (MRSA). Sci Res Essay 2009, 4:351-356.

31. Camarda L, Dayton T, Di Stefano V, Pitonzo R, Schillaci D: Chemical composition and antimicrobial activity of some oleo gum resin essential oils from Boswellia spp. (Burseraceae). Ann Chim 2007, 97(9):837-44.

32. Kasali AA, Adio AM, Kundaya OE, Oyedeji AO, Eshilokun AO, Adefenwa M: Antimicrobial activity of the essential oil of Boswellia serrata Roxb. J Essent Oil Bearing Plants 2002, 5(3):173-175.

33. Weckessera S, Engela K, Simon-Haarhausa B, Wittmerb A, Pelzb K, Schemppa CM: Screening of plant extracts for antimicrobial activity against bacteria and yeasts with dermatological relevance. Phytomedicine 2007, 14:508-516.

34. Hancock RE: The bacterial outer membrane as a drug barrier. Trends Microbiol 1997, 5:37-42

35. Helander IM, Alakomi HL, Latva-Kala K, Mattila-Sandholm T, Pol I, Smid EJ, Gorris LJ, Von Wright T: Characterization of the action of selected essential oil components on Gram-negative bacteria. J Agric Food Chem 1998, 46:3590-3595.

36. Gallucci MN, Oliva M, Casero C, Dambolena J, Luna A, Zygadlob J, Demo M: Antimicrobial combined action of terpenes against the food-borne microorganisms Escherichia coli, Staphylococcus aureus and Bacillus cereus. Flavour Fragr J 2009, 24:348-354.

37. Trombetta D, Castelli F, Grazia MS, Venuti V, Cristani M, Daniele C, Saija A, Mazzanti G, Bisignano G: Mechanisms of Antibacterial Action of Three Monoterpenes. Antimicrob Agents Chemother 2005, 49:2474-2478.

38. Reddy MV, Thota N, Sangwan PL, Malhotra P, Ali F, Khan IA, Chimni SS, Koul S: Novel bisstyryl derivatives of bakuchiol: targeting oral cavity pathogens. Eur J Med Chem 2010, 45:3125-3134. 
39. Burlando B, Parodi A, Volante A, Bassi AM: Comparison of the irritation potentials of Boswellia serrata gum resin and of acetyl-11-keto-boswellic acid by in vitro cytotoxicity tests on human skin-derived cell lines. Toxicol Lett 1993, 177:144-149.

40. Magesh V, Raman D, Pudupalayam KT: Genotoxicity studies of dry extract of Boswellia serrata. Tropical J Pharmaceutical Research 2008, 7(4):1129-1135.

41. Shah BA, Kumar A, Gupta P, Sharma M, Sethi VK, Saxena AK, Singh J, Qazi GN, Taneja SC: Cytotoxic and apoptotic activities of novel amino analogues of boswellic acids. Bioorg Med Chem Lett 2007, 17:6411-6416.

42. Ammon HP, Safayhi H, Mack T, Sabieraj J: Mechanism of antiinflammatory actions of curcumine and boswellic acids. J Ethnopharmacol 1993, 38:113-119.

43. Abdel TM, Kaunzinger A, Bahr U, Karas M, Wurglics M, SchubertZsilavecz M: Development of a high performance liquid chromatographic method for the determination of 11 keto beta boswellic acid in human plasma. $J$ Chromatogr Biomed Appl 2001, 761:221-227.

44. Buechele B, Simmet T: Analysis of 12 different pentacyclic triterpenic acids from frankincense in human plasma by high performance liquid chromatography and photodiode array detection. J Chromatogr 2003, 795:355-362

45. Sharma S, Thawani V, Hingorani L, Shrivastava M, Bhate VR, Khiyani R: Pharmacokinetic study of 11 keto beta boswellic acid. Phytomedicine 2004, 11:1255-1260.

46. Reising K, Meins J, Bastian B, Eckert G, Mueller WE, Schubert-Zsilavecz M, Abdel Tawab M: Determination of boswellic acids in brain and plasma by high-performance liquid chromatography/tandem mass spectrometry. Anal Chem 2005, 77:6640-6645.

47. Sterk V, Buchele B, Simmet T: Effect of food intake on the bioavaliability of boswellic acids from an herbal preparation in healthy volunteers. Planta Med 2004, 70:1155-1160.

48. Clinical and Laboratory Standards Institute: Methods for dilution antimicrobial susceptibility tests for bacteria that grow aerobically. Approved standard. M7-A7. 7 edition. Wayne, PA: CLSI; 2006.

49. Eliopoulus GM, Moellering RCJ: Antimicrobial combinations. In Antibiotics in Laboratory Medicine. 4 edition. Edited by: Lorian V. Baltimore, MD: The Williams 1996:330-396.

50. Craig WA, Gudmundsson S: Postantibiotic effect. In Antibiotics in laboratory medicine. 4 edition. Edited by: Lorian V. Williams and Wilkins Co., Baltimore, MD; 1996:296-329

51. Wei GX, Campagna AN, Bokek LA: Effect of MUC7 peptides on the growth of bacteria and on Streptococcus mutans biofilm. J Antimicrob Agents 2006, 57:1100-1109.

52. Cox SD, Mann CM, Markham JL, Bell HC, Gustafson JE, Warmington JR, Wyllie SG: The mode of antimicrobial action of the essential oil of Melaleuca alternifolia (tree oil). J App Microbio 2000, 88:170-175.

53. Lo'pez-Amoro's R, Comas J, Vives-Rego J: Flow cytometric assessment of Escherichia coli and Salmonella typhimurium starvation-survival in seawater using rhodamine 123, propidium iodide, and oxonol. Appl Environ Microbiol 1995, 61:2521-2526.

54. Hilliard JJ, Goldschmidt RM, Licata L, Baum EZ, Bush K: Multiple mechanisms of action for inhibitors of histidine protein kinases from bacterial two-component systems. Antimicrob Agents Chemother 1999, 43:1693-1699.

55. Cox SD, Mann CM, Markham JL, Gustafson JE, Warmington JR, Wyllie SG: Determining the Antimicrobial Actions of Tea Tree Oil. Molecules 2001, 6:87-91.

doi:10.1186/1471-2180-11-54

Cite this article as: Raja et al:: Antistaphylococcal and biofilm inhibitory activities of acetyl-11-keto- $\beta$-boswellic acid from Boswellia serrata. BMC Microbiology 2011 11:54.

\section{Submit your next manuscript to BioMed Central and take full advantage of:}

- Convenient online submission

- Thorough peer review

- No space constraints or color figure charges

- Immediate publication on acceptance

- Inclusion in PubMed, CAS, Scopus and Google Scholar

- Research which is freely available for redistribution

Submit your manuscript at www.biomedcentral.com/submit
Biomed Central 